\author{
DARIUSz IWAN, DOMINIKA MierzWA-SzYMKOWIAK, WiOletTA WAWER
}

\author{
Muzeum i Instytut Zoologii PAN \\ Wilcza 64, 00-679 Warszawa \\ E-mail: darek@miiz.waw.pl \\ dmierzwa@miiz.waw.pl \\ wawer@miiz.waw.pl
}

\title{
ZBIORY PRZYRODNICZE MUZEUM I INSTYTUTU ZOOLOGII PAN - ŚWIADECTWO POLSKIEGO WKŁADU W ROZWÓJ ŚWIATOWYCH BADAŃ BIORÓŻNORODNOŚCI PROWADZONYCH OD POCZĄTKU XIX WIEKU
}

\section{WSTEP}

Gromadzone od dwóch stuleci zbiory zwierząt współczesnych Muzeum i Instytutu Zoologii PAN (MiIZ PAN) stanowia bezcenną część światowego dziedzictwa przyrodniczego. Imponują wartościa naukowa, historyczną i kulturowa, a także różnorodnościa, unikatowościa i proweniencją (Ryc. 1, 2). Szacowane na 7000000 okazów, stanowia podstawę wieloletniej współpracy instytucji $z$ ponad 200 placówkami muzealnymi i naukowymi na świecie. Sa tworzone $z$ wielkim zaangażowaniem, znawstwem oraz pasja i sa przedmiotem licznych opracowań naukowych. Z elektronicznych zasobów danych dotyczacych tych największych w Polsce zbiorów korzystaja tysiące użytkowników. W ramach działalności Krajowej Sieci Informacji o Bioróżnorodności (KSIB) od 2010 r. przekazano na platformę internetowa GBIF 11 baz danych liczacych ponad 90000 rekordów (https://www.gbif.org/publisher/ e147be40-75eb-11d9-b257-b8a03c50a862). W 2020 r. portal Global Biodiversity Information Facility (GBIF) zarejestrował blisko $17500000 \mathrm{mln}$ pobrań rekordów informacji z baz reprezentujaccych zbiory MiIZ PAN. W wyniku digitalizacji prowadzonej w ramach obecnie realizowanego projektu pt. „Integracja i mobilizacja danych o różnorodności biotycznej Eukaryota w zasobach polskich instytucji naukowych" (IMBIO) informacje o zbiorach zoologicznych MiIZ PAN zostana powiększone o kolejnych ponad 300000 rekordów.

\section{ZNACZENIE ZBIORÓW MUZEALNYCH DLA BADAN NAUKOWYCH}

Materiały muzealne maja kluczowe znaczenie w dokumentowaniu różnorodności biologicznej, a także przeszłego i obecnego rozmieszczenia geograficznego zwierzat. Stanowia materiał dowodowy do badań zarówno $z$ zakresu systematyki, jak też anatomii, fizjologii, cytologii, biochemii, ekologii czy genetyki. Podstawa tego sa prawidłowo oznaczone gatunki, a także dostęp do okazów muzealnych (Ryc. 3). Umożliwia to $z$ jednej strony porównanie i identyfikacje materiałów biologicznych, $z$ drugiej zaś zapewnia powtarzalność badań i weryfikację hipotez. W wielu przypadkach możliwe jest także rozszerzenie prac o nowe techniki badawcze jak mikrotomografia rentgenowska czy mikroskopia skaningowa. Najważniejsze w zbiorach okazy, tzw. typy deskrypcyjne (Ryc. 4) wyznaczane przez autora opisu gatunku nowego dla wiedzy lub późniejszych badaczy, sa wykorzystywane do rozpoznawania, weryfikowania i opisywania nazw taksonów (IWAN 2007).

Zapisane informacje na etykietach dołączonych do okazów muzealnych dowodza obecności gatunków w określonym czasie i przestrzeni. Od wielu lat dokumentację tego

Słowa kluczowe: bioróżnorodność, dziedzictwo narodowe, kolekcja naukowa, Muzeum i Instytut Zoologii Polskiej Akademii Nauk, okazy muzealne, zbiory przyrodnicze

*Artykuł powstał dzięki wsparciu finansowemu z projektu POPC.02.03.01-00-0081/19 „Integracja i mobilizacja danych o różnorodności biotycznej Eukaryota w zasobach polskich instytucji naukowych” (IMBIO). 


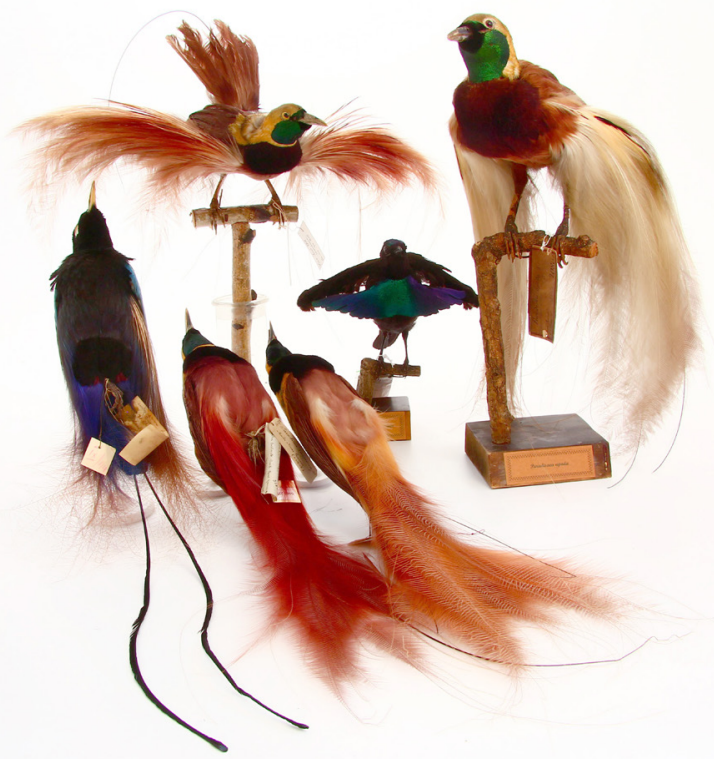

Ryc. 1. Historyczne preparaty ptaków rajskich $z$ Nowej Gwinei, w tym okazy $z$ kolekcji Ksawerego Branickiego, fot. D. Mierzwa-Szymkowiak.

typu uzupełniaja fotografie lub/i nagrania dźwiękowe, choć nie są one wystarczajace do badań naukowych. Dlatego wciąż istnieje potrzeba gromadzenia kolekcji naukowych. Wiele okazów zebranych kilkadziesiąt lat temu stanowi obecnie muzealne unikaty, ponieważ siedliska, z których pochodzą zostały przekształcone lub utracone, natomiast reprezentowane przez nie populacje gatunku wyginęly lub sa zagrożone wymarciem. Materiały tego typu pomagaja udokumentować zmiany klimatyczne oraz zagrożenia prowa-

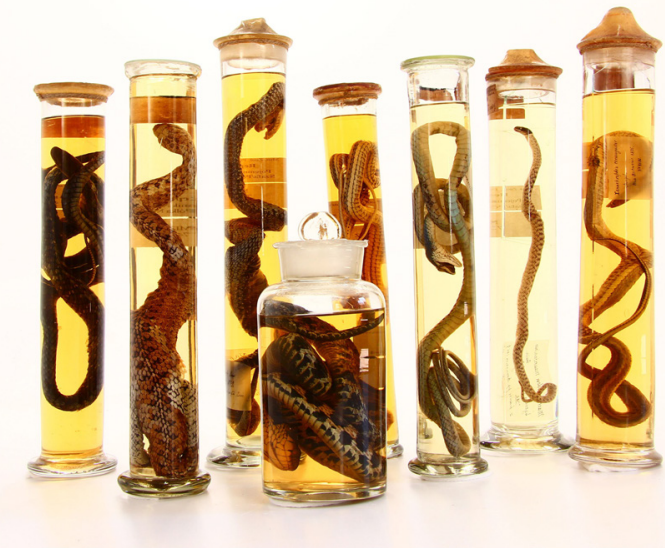

Ryc. 2. Preparaty mokre gadów afrykańskich, azjatyckich i południowoamerykańskich m.in. $z$ kolekcji Konstantego Jelskiego, Benedykta Dybowskiego, Aleksandra i Konstantego Branickich, fot. D. Mierzwa-Szymkowiak.

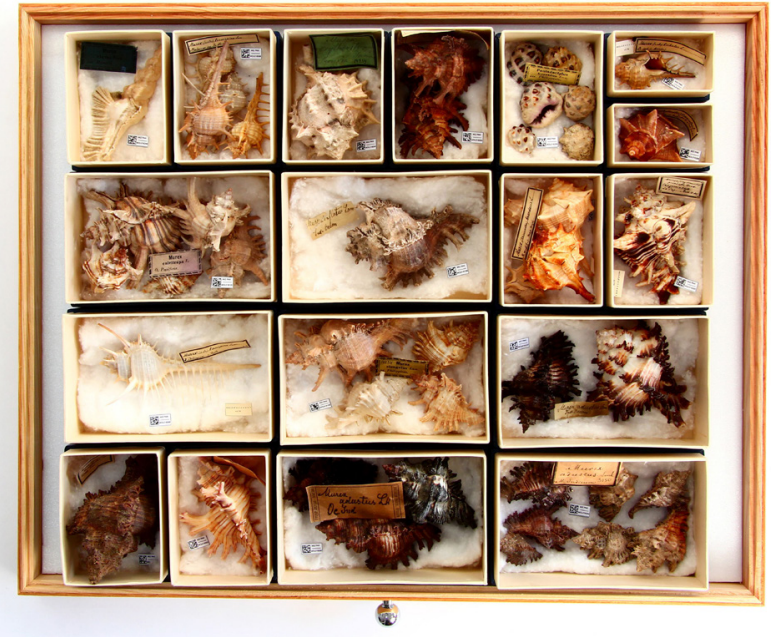

Ryc. 3. Muszle mięczaków morskich m.in. $z$ kolekcji Gabinetu Zoologicznego, fot. D. Mierzwa-Szymkowiak.

dzace do nieodwracalnych zmian $\mathrm{w}$ środowisku przyrodniczym. Dostarczaja zatem niezbędnych informacji do badań ekologicznych i ewolucyjnych, a także prac zwiazanych $z$ zarzadzaniem zasobami przyrodniczymi, ich monitorowaniem oraz planowaniem skutecznych strategii ochrony. Analiza sekwencji DNA $z$ fragmentów ciała wyodrębnionych $z$ różnowiekowych okazów pozwalają dodatkowo na poznanie zależności oraz zmian za-

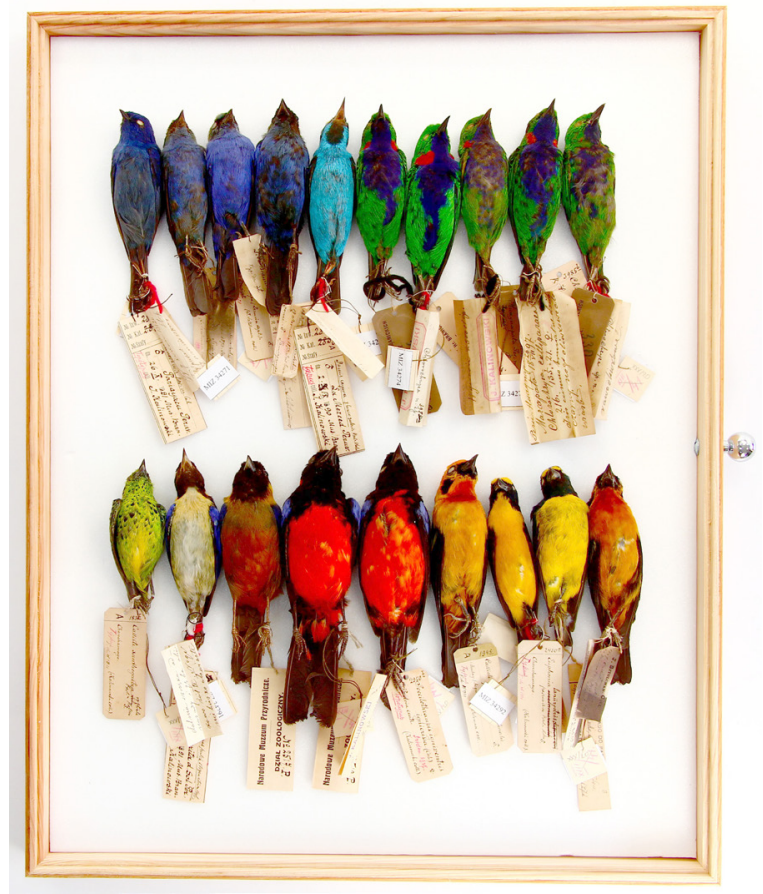

Ryc. 4. Okazy typowe ptaków południowoamerykańskich w formie „skórek” z kolekcji Jana Sztolcmana i Jana Kalinowskiego, fot. D. Mierzwa-Szymkowiak. 


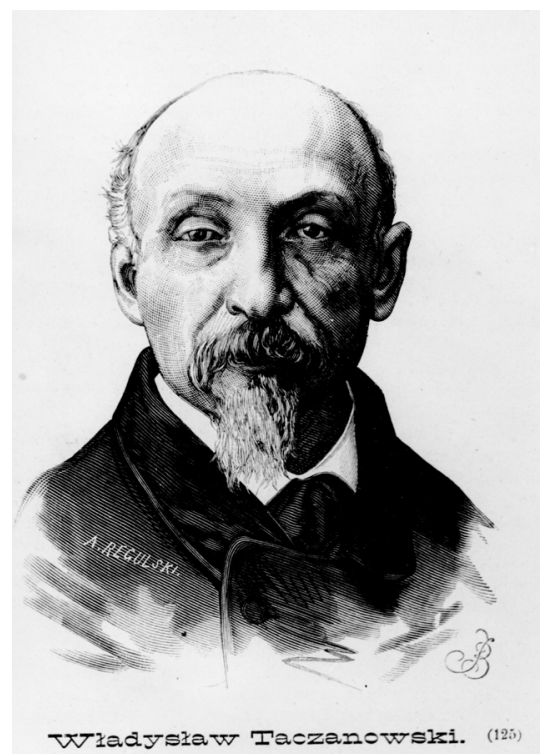

Ryc. 5. Władysław Taczanowski (1819-1890). Archiwum MiIZ PAN.

chodzacych w obecnych i wymarłych populacjach. Informuja także o kondycji badanej populacji, co jest szczególnie ważne, gdy ich liczebność ulega obecnie dramatycznemu spadkowi (RAVEN i WAGNER 2021). Z kolei serie okazów danego gatunku umożliwiaja badania np. dotyczące różnic i podobieństw populacji pochodzących $z$ odległych geograficznie regionów.

Gromadzenie informacji w spójnych systemach informatycznych pozwala na katalogowanie zbiorów i skuteczne nimi zarządzanie. Możliwe jest tworzenie map rozmieszczenia gatunków, a także modelowanie ich wymagań klimatycznych i środowiskowych. Takie mapy dla terenów cennych przyrodniczo służą do planowania badań, analizowania aktualnego stanu przyrody i prognozowania zachodzacych w niej zmian. Pozwalaja także integrować działania na rzecz ochrony różnorodności biologicznej.

\section{HISTORIA I ROZWÓJ KOLEKCJI ZOOLOGICZNYCH MIIZ PAN}

Najstarsze zbiory Muzeum i Instytutu Zoologii PAN licza ponad 200 lat i pochodza $z$ czasów Gabinetu Zoologicznego Uniwersytetu Warszawskiego. Wśród nich wyróżniają się okazy ptaków i ssaków zakupione w 1818 r. od sukcesorów ślasskiego barona Sylwiusza Münkwitza (1772-1818). Zbiór ten pierwotnie obejmował około 20000 okazów pochodzacych m.in. $z$ obszarów Europy i Ameryki Południowej (DASZKIEWICZ i współaut. 2016). Z powodu burzliwej historii Polski do dzisiaj zachowała się tylko nieliczna część eksponatów Münkwitza.

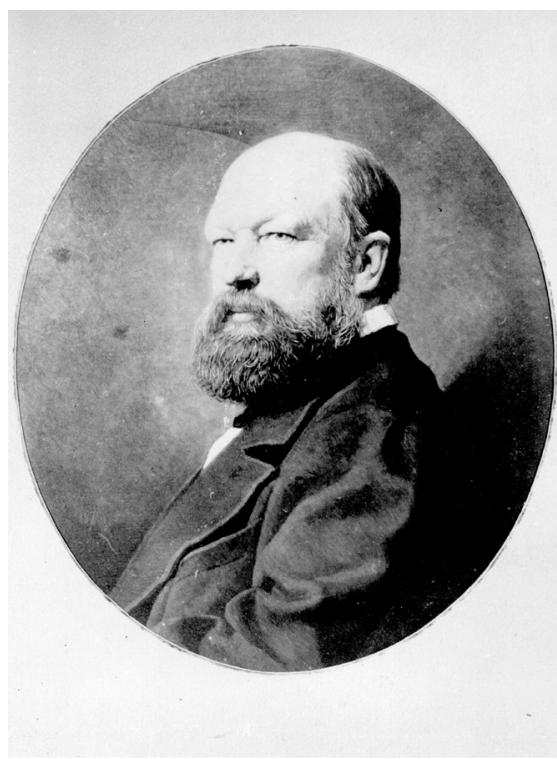

Ryc. 6. Aleksander Branicki (1821-1877). Archiwum MiIZ PAN.

W tym samym okresie nabyto do Gabinetu od spadkobierców księżnej Zofii Lubomirskiej (1718-1790) zbiór mięczaków liczący około 9000 okazów $z$ całego świata (KoWALSKA 1987e). Najstarsze zasoby muzealne obejmuja również zbiór ptaków krajowych Władysława Taczanowskiego (1819-1890) (Ryc. 5), kustosza Gabinetu Zoologicznego w latach 1862-1890 (BRZËK 1959). Zbiór Taczanowskiego, skompletowany przed objęciem stanowiska w Gabinecie, szacowany był na kilkaset ptaków, a obecnie obejmuje zaledwie kilkadziesiąt egzemplarzy.

Nieco późniejsze zbiory Gabinetu Zoologicznego, o których warto także wspomnieć, obejmują materiały zarówno bezkręgowców (głównie owady, pajęczaki i mięczaki), jak i kręgowców (głównie ryby, gady, ptaki i ssaki), pochodzace $z$ wypraw zapoczątkowanych w 1863 r. przez hrabiów Aleksandra (18211877) i Konstantego Branickich (1824-1884) (Ryc. 6, 7). Odbywali oni podróże po krajach Europy i Afryki, a zgromadzone zbiory przekazywali w postaci darów do Gabinetu. Prace terenowe kontynuował Konstanty Jelski (1837-1896) (Ryc. 8), przekazujacc od 1866 r. zbiory $z$ Gujany Francuskiej, a od 1871 r. jako eksplorator Branickich, zbiory $z$ Peru. W latach 1875-1884 badania w Peru, a następnie w Ekwadorze rozwijał wspierany przez Branickich, Jan Sztolcman (1854-1928) (Ryc. 9). Dostarczył on, podobnie jak inni przyrodnicy, okazy reprezentujące tysiące gatunków, w tym wiele nowych dla nauki. $Z$ ramienia Branickich, zbiory dla Gabinetu Zoologicznego gromadzili także Ludwik Młokosiewicz (1831-1909) na Kaukazie, Michał Jankowski (1843?-1912?) w 


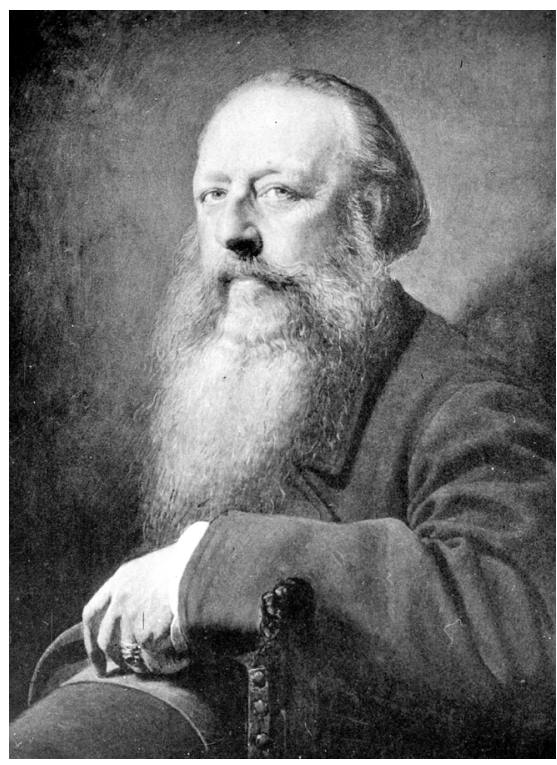

Ryc. 7. Konstanty Branicki (1824-1884). Archiwum MiIZ PAN.

Rosji i Władysław Garliński w Turkiestanie. Od 1865 r. warszawskie zbiory wzbogacali Benedykt Dybowski (1833-1930), badacz Bajkału i Kamczatki, wraz $z$ towarzyszami zesłania Wiktorem Godlewskim (1831-1900) i Alfonsem Parvexem (1833?-1890) (BRZEK 1959).

W 1887 r. Ksawery Branicki (1864-1926) otworzył w Warszawie Muzeum Branickich. Placówka projektowana przez jego ojca Konstantego Branickiego miała na celu uchronienie zbiorów zoologicznych przed ewentualna konfiskata przez władze rosyjskie (IwAN i DASZKIEWICZ 2019). Trzonem tego muzeum był zbiór ptaków południowoamerykańskich i

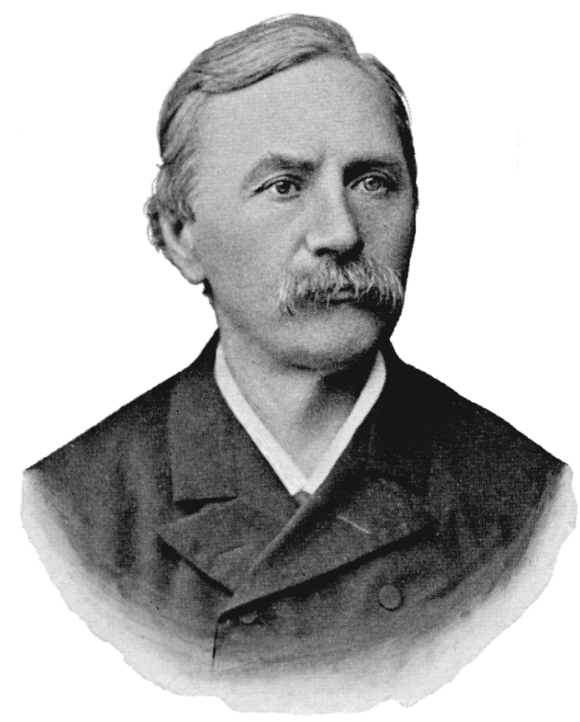

Ryc. 8. Konstanty Jelski (1837-1896). Archiwum MiIZ PAN.

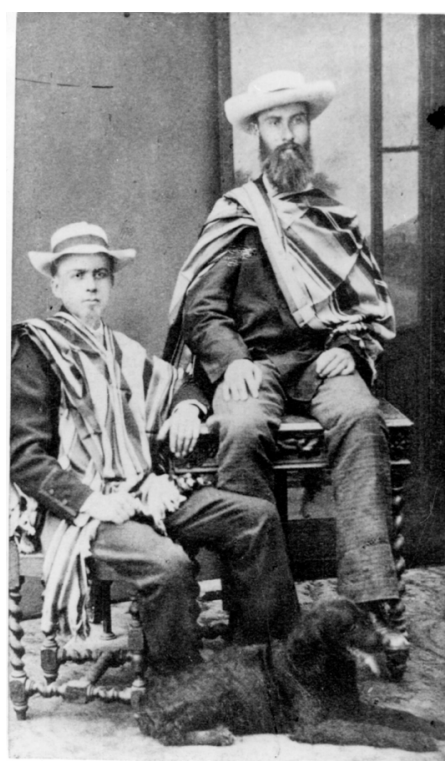

Ryc. 9. Jan Sztolcman (1854-1928) i Józef Siemiradzki (1858-1933) podczas wyprawy do Ekwadoru (1883). Archiwum MiIZ PAN

azjatyckich, a także innych wymienianych $z$ najważniejszymi muzeami zoologicznymi Europy i Stanów Zjednoczonych Ameryki. Nowe materiały pochodziły również $z$ regularnych zakupów dokonywanych przez Ksawerego Branickiego, jak np. nabyte w Paryżu duże zbiory ptaków rajskich (cudowronek) z Nowej Gwinei (DASZKIEWICZ i IWAN 2020).

W 1919 r. powołano Narodowe $\mathrm{Mu}-$ zeum Przyrodnicze w Warszawie, którego Dział Zoologiczny powstał w wyniku połączenia zbiorów Gabinetu Zoologicznego i Muzeum Branickich (IWAN i DASZKIEWICZ

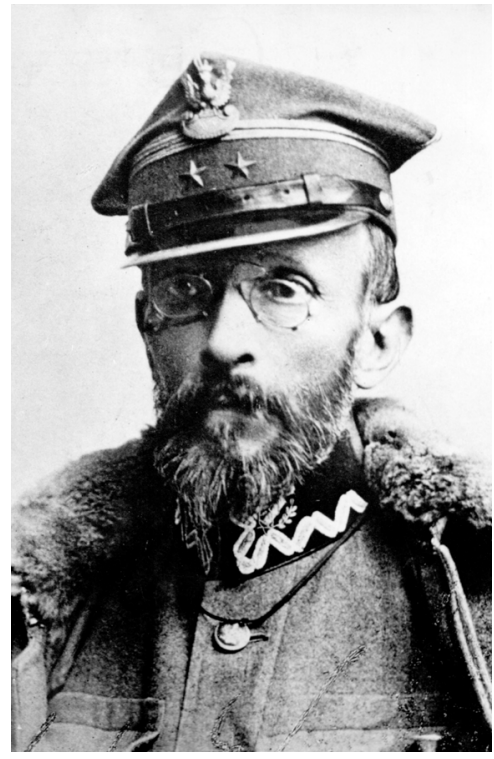

Ryc. 10. Antoni Wagner (1860-1928). Archiwum MiIZ PAN. 


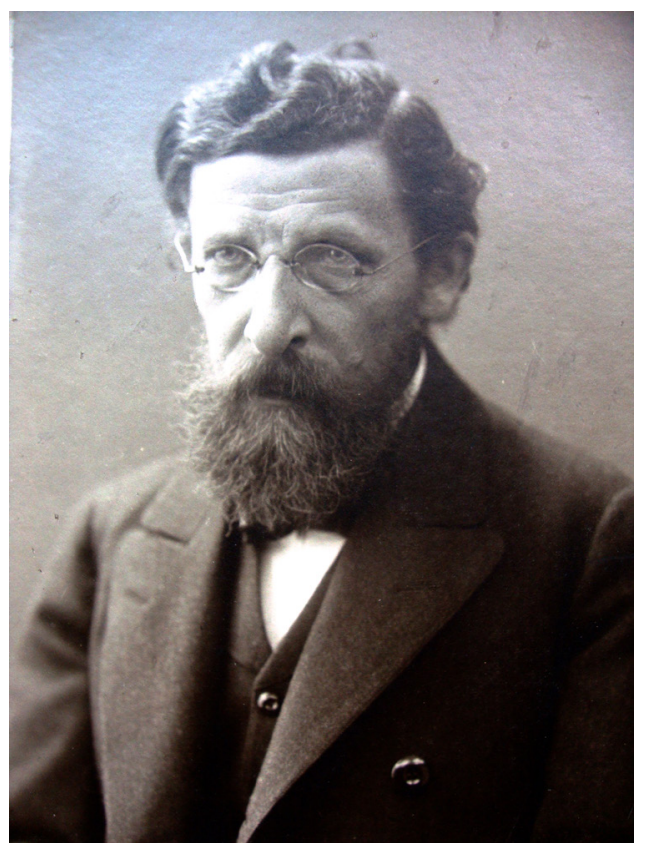

Ryc. 11. Władysław Kulczyński (1854-1919). Archiwum MiIZ PAN.

2019). Od 1921 r. instytucja funkcjonowała pod nazwa Polskie Państwowe Muzeum Przyrodnicze, natomiast od 1928 r.

- Państwowe Muzeum Zoologiczne (PMZ). Kontynuowało ono długoletnia tradycję eksploratorska i kolekcjonerska. Nowe materiały pochodziły $z$ czterech głównych źródeł: podróże/ekspedycje pracowników i współpracowników, zakupy, darowizny i wymiana. Wykaz materiałów nabytych od przyrodników krajowych i zagranicznych zestawił szczegółowo Antoni Wagner (18601928) w sprawozdaniach $z$ działalności muzeum za lata 1919-1928 (Ryc. 10). $\mathrm{Na}$ ich podstawie stwierdza się, że już w pierwszych latach funkcjonowania muzeum (1919-1921) zakupiono zbiór pajęczaków Władysława Kulczyńskiego (1854-1919) (Ryc. 11) obejmujacy około 6000 gatunków europejskich i egzotycznych. W tym czasie Muzeum otrzymało w darze również dwa zbiory mięczaków (każdy liczył około 8000 gatunków) pochodzacych $z$ różnych regionów świata. Pierwszy darowali spadkobiercy księcia Władysława Emanuela Lubomirskiego (1824-1882) (Ryc. 12), drugi przekazał Antoni Wagner (WAGNER 1926a). W latach 1922-1924 do najważniejszych nabytków zaliczono zbiory pozyskane w Brazylii przez Polska Wyprawę Zoologiczną. Wśród nich najliczniejsze były owady, szacowane na 20000 okazów, i ptaki obejmujące ponad tysiąc okazów. Materiały dodatkowo obejmowały inne grupy zwierzat jak: wije, mięczaki, pajęczaki, płazy, gady i ssaki. Zbiory brazylijskie darował również

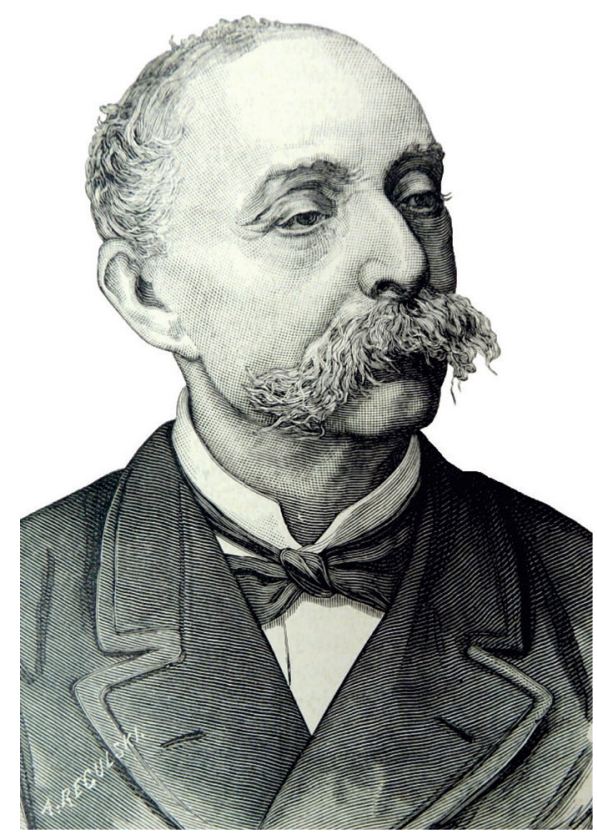

Ryc. 12. Władysław Lubomirski (1824-1882). Archiwum MiIZ PAN.

polski emigrant Józef Czaki (1857-1946). Liczyły one ponad 22000 okazów owadów, w tym około 10000 motyli. Mniej liczne były: wije, skorupiaki, mięczaki, pajęczaki, szkarłupnie, ptaki i ssaki (WAGNER $1926 b, c, d)$. Kolejne dary, obejmujace okazy zwierzat brazylijskich, wpłynęły do muzeum w 1925 r. Obejmowały one ponad 2000 okazów owadów zebranych przez Czakiego i około 500 ptasich skórek pozyskanych przez Tadeusza Chrostowskiego (1878-1923) (WAGNER 1926e). Rok później Muzeum wzbogaciło się o kolejne materiały, wśród których najliczniejsze przekazal Szymon Tenenbaum (1892-1941) (patrz IWAN i DASZKIEWICZ w tym zeszycie KOSMOSU). Na uwage zasługuje ponad 7000 okazów pluskwiaków z Balearów, około 2000 innych grup owadów (głównie pluskwiaki i motyle) i ponad 800 okazów mięczaków zebranych razem $z$ Tadeuszem Wolskim (1890-1959) w Meksyku, na Kubie i w Hiszpanii (WAGNER 1926f). Dary Tenenbauma obejmowały także: skorupiaki, wije, pajęczaki, owady, ryby, gady i ssaki zebrane w Palestynie. W 1927 r. wpłynęły do Muzeum dwa duże dary obejmujace owady krajowe. Tadeusz Jaczewski (1899-1974) przekazał około 8000 pluskwiaków, natomiast Jerzy Kremky (1897-1941) - około 3500 motyli i 500 chrząszczy (WAGNER 1928). Materiały ważne dla rozwoju naszych zbiorów przekazali w 1928 r. Benedykt Dybowski (1833-1930) i Jan Grochmalicki (1883-1936). Obejmowały one około 5000 okazów mięczaków $z$ Bajkału, Morza Kaspijskiego, Morza Japoń- 
skiego i rzek należacych do zlewiska Morza Czarnego (WAGNER 1929).

Pożar w muzeum w 1935 r. spowodował utratę znacznej części zbiorów. Natomiast druga wojna światowa (1939-1945) doprowadziła do wieloletniej przerwy w działalności instytucji, a także zniszczenia, poważnego uszkodzenia i zaginięcia licznych okazów (DASZKIEWICZ i współaut. 2016). W okresie powojennym placówka koncentrowała sie na odbudowie $i$ uzupełnianiu utraconych zbiorów. W 1947 r. Witold Eichler (1874-1960) przekazal nowe materiały obejmujace około 200 okazów ptaków, a w latach 1950-1951 około 500 okazów chrząszczy z podróży po Afryce (m.in. Algieria, Maroko, Rodezja). W późniejszym czasie stały się one częścia jednego $z$ największych zbiorów przechowywanych $\mathrm{w}$ muzeum, mianowicie zbioru Eichlera przekazanego $\mathrm{w}$ zapisie testamentowym w 1963 r., który liczył około 200000 okazów, głównie entomologicznych (FELIKSIAK 1987a). W 1950 r. muzeum nabyło zbiory Arkadego Fiedlera (1894-1985) i Bogdana Kreczmera (1908-1987) z Madagaskaru. Obejmowały one ponad 3000 okazów, w tym m.in. krocionogi, motyle, mięczaki, gady, ryby i ptaki.

W 1952 r. powołano Instytut Zoologiczny PAN (obecnie Muzeum i Instytut Zoologii PAN), którego działalność wyrażała sie m.in. poprzez badania terenowe $\mathrm{w} \mathrm{kra-}$ ju i za granica (głównie w Europie i Azji). Wyjazdy pracowników wzbogaciły zbiory o tysiące okazów należących do setek gatunków i typów opisowych. $Z$ tego czasu liczne kolekcje pochodza także od współpracowników muzeum. W latach 19561997 regularnie dary przekazywał Borys Malkin (1917-2009). Ostatni nabytek z materiałami tego przyrodnika wpłyną do muzeum w 2010 r., za pośrednictwem jego żony Heleny Przestalskiej-Malkin. Zawierały one łącznie ponad 16000 okazów, wśród których dominowały chrząszcze i mięczaki zebrane przez Malkina m.in. w USA, Peru, Brazylii, Kolumbii, Ekwadorze, Grecji, Hiszpanii i Szwajcarii. Zbiory muzealne wzbogacił również Jan Maciej Rembiszewski, kierownik Polskiej Stacji Antarktycznej im. Henryka Arctowskiego. Jego dary $z$ lat 1972, 1974 i 1976 obejmowały ponad 700 okazów, przede wszystkim ryby $z$ Arktyki i Antarktydy. W ostatnim czasie jednym $z$ większych darów był zbiór chrząszczy Andrzeja Szujeckiego (1929-2017). Został on przekazany przez jego rodzinę w 2018 r. Liczy on ponad 21000 okazów $z$ różnych regionów świata i jest jednym $z$ pierwszych włączonych do projektu IMBIO.

\section{OD GABINETU HISTORII NATURALNEJ DO WSPÓŁCZESNYCH KOLEKCJI}

\section{KOLEKCJA MALAKOLOGICZNA}

Historia kolekcji malakologicznej sięga początków XIX w. i zwiazana jest $z$ utworzeniem Gabinetu Zoologicznego przy Królewskim Uniwersytecie Warszawskim. Już w pierwszym okresie funkcjonowania Gabinetu, mianowicie w 1818 r., nabyto od hrabiny Rozalii Rzewuskiej (1791-1865) zbiór muszli obejmujacy około 9000 okazów (KowALSKA 1987e). Pierwotnie zbiór ten należał do księżnej Zofii Lubomirskiej (1718-1790) i wchodził w skład Gabinetu Historii Naturalnej znajdujaccego się w jej majątku w Opolu Lubelskim (ROLSKA-BORUCH 1999, JASTRZĘBSKA 2005, LUBOMIRSKI-LANCKOROŃSKI 2018). Bogaty w okazy Gabinet odziedziczył i pomnażał ksiażę Aleksander Lubomirski (17511804). Dzięki jego córce Rozalii Rzewuskiej większa część zbioru została przekazana do gabinetu przyrodniczego szkoły pijarów w Opolu Lubelskim, natomiast mniejsza do kolekcji malakologicznej Gabinetu Zoologicznego w Warszawie (KowALSKA 1987a, e).

W kolejnych latach kolekcja była wzbogacana dzięki mecenasom Gabinetu: hrabiom Aleksandrowi i Konstantemu Branickim oraz księciu Władysławowi Emanuelowi Lubomirskiemu (WRZEŚNIOWSKI 1883, SZTOLCMAN 1890, SUCHODOLSKI i współaut. 1983, MiERZWA-SZYMKOWIAK i BREURE 2017). Braniccy byli zamiłowanymi podróżnikami, sami pozyskiwali okazy lub kupowali je w wyspecjalizowanych firmach handlowych i zagranicznych muzeach (DASzKIEWICZ i współaut. 2016). W kolekcji Gabinetu znalazły się m.in. muszle zakupione przez Aleksandra Branickiego we Francji, a także pozyskane przez braci Branickich podczas wypraw do Egiptu, Nubii (1861-1862) i Algierii (1866-1867) (TACZANOWSKI 1884; KoWALSKA 1987b, c). Lubomirski dotował zakupy okazów i wydawnictwa Gabinetu (KAzUBSKI 1996). Wspólnie $z$ Antonim Ślósarskim (1843-1897) przyczynił się do oznaczenia gatunków i uporzadkowania zbioru (WRZEŚNIOWSKI 1882, MIERZWA-SZYMKOWIAK i BREU$\mathrm{RE}$ 2017). Kolekcję sukcesywnie uzupełniali przyrodnicy, których prace badawcze, prowadzone w różnych częściach świata, były objęte mecenatem Branickich i Lubomirskiego. Wymienia się tutaj między innymi badania Konstantego Jelskiego w Gujanie Francuskiej i Peru w latach 1866-1872, Jana Sztolcmana w Peru i Ekwadorze, w okresie 1872-1881 i Benedykta Dybowskiego na Syberii, około 1867-1872 (KoWALSKA 1987c, d, f; PAWŁOWSKI 2006; TARKOWSKI 2011; DASZKIEWICZ i współaut. 2016; PIECHNIK i KUREK 
2016; MIERZWA-SZYMKOWIAK i BREURE 2017). Niewątpliwie do najważniejszych materiałów malakologicznych zalicza się te, które posłużyły do poznania malakofauny Bajkału przez Benedykta Dybowskiego i jego brata Władysława (1839-1910) (BRZEK 1994).

Od 1867 r. ksiązę Lubomirski rozpoczął do autorskiego zbioru intensywne gromadzenie muszli mięczaków $z$ całego świata. Okazy nabywał głównie droga zakupu w wyspecjalizowanych firmach handlowych. W ciagu 15 lat stworzył pierwszy w Polsce naukowy zbiór konchyliów liczacy około 8000 gatunków (ponad 40000 okazów). Zajmował się również naukowym opracowaniem ślimaków południowoamerykańskich nadsyłanych przez Jelskiego i Sztolcmana (POKRYSZKO i RIEDEL 1999, RIEDEL i POKRYSZKO 1999). Napisał dwie prace: Note sur une nouvelle espèce de Guesteria Crosse (Paryż, 1879), w której opisal nowy gatunek Guesteria branickii i Notice sur quelques Coquilles du Pérou (London, 1879) Z opisem 44 gatunków, w tym 8 nowych dla nauki (KowALSKA 1973, 1987f; MIERZWA-SZYMKOWIAK i BREURE 2017). Po śmierci Lubomirskiego zbiór muszli przechowywano w postaci depozytu w Muzeum Branickich w Warszawie (SzTOLCMAN 1888, BRZEK 1959, DASZKIEWICZ i IWAN 2020). W 1919 r. Narodowe Muzeum Przyrodnicze otrzymało w darze zbiór księcia Lubomirskiego, za sprawa jego brata Stefana Lubomirskiego (1819-1900) (WAGNER 1926a).

Dalszy rozwój kolekcji zapewniła działalność malakologa Antoniego Wagnera, który w 1921 r. obją stanowisko dyrektora w warszawskim Muzeum. Przekazał mu zbiór mięczaków obejmujący około 8000 gatunków, w tym kilkaset typów deskrypcyjnych (POLIŃSKI 1929). Materiały pochodziły w dużej mierze $z$ badań faunistycznych prowadzonych przez Wagnera na obszarach byłej Monarchii Austro-Węgierskiej. Część materiałów, szczególnie tych spoza Europy, pozyskał w drodze wymiany lub zakupu. Jego zbiór obejmuje muszle m.in. z Kuby, Kostaryki, Japonii i Filipin otrzymane od zagranicznych malakologów jak Oscar Boettger (1844-1910), Philippe Dautzenberg (18491935), William Dell Hartman (1817-1899), Yoichirō Hirase (1859-1925), Eduard von Martens (1831-1904) i Otto Frantz von Moellendorff (1848-1903) (RICHLING 2005). Wagner w swoich pracach, przeważnie o charakterze monograficznym, koncentrował się na ślimakach $z$ rodzin Helicinidae i Clausiliidae, w których wyznaczył wiele nowych taksonów (FELIKSIAK 1987d, RICHLING 2005). Wnikliwie studiował także malakofaunę Półwyspu Bałkańskiego (FELIKSIAK 1987d). Główną zasługa Wagnera było zastosowanie cech anatomicznych w taksonomii szcze- bla rodzajowego i gatunkowego. Metoda ta, która kończyła okres „czystej konchologii” w czasach Wagnera, stanowiła przełom i dziś jest powszechnie stosowana (RIEDEL i PoKRYSZKO 1999).

Wzbogacenie kolekcji malakologicznej w liczne materiały krajowe zawdzięczamy Władysławowi Polińskiemu (1885-1930), kustoszowi (1918-1919) i p.o. dyrektora muzeum (1928-1929). Dzięki jego badaniom stan znajomości malakofauny w Polsce środkowej i północno-wschodniej dorównał byłej Galicji (RIEDEL i POKRYSZKO 1999). Studia Polińskiego nad ślimakami lądowymi miały charakter systematyczny, faunistyczny i zoogeograficzny. Koncentrował się na ślimakach $z$ rodziny Helicidae $z$ obszarów Polski, a także niektórych krajów bałkańskich i alpejskich (FELIKSIAK 1987c, RIEDEL i POKRYSZKO 1999). Poliński kontynuował również działalność naukowa Lubomirskiego, opisujacc nowe taksony $\mathrm{w}$ oparciu o materiały Jelskiego i Sztolcmana $z$ Ameryki Południowej. Jednak najważniejsze dla światowej malakologii opracowanie Polińskiego dotyczy fauny macedońskiego Jeziora Ochrydzkiego, porównywanego w Palearktyce tylko $z$ fauna Bajkału i Morza Kaspijskiego (FELIKSIAK 1987c). W późniejszym czasie materiały muzealne Polińskiego porządkował i oznaczał Antoni Jankowski (1874-1945). Wzbogacił on również zbiór krajowy w muszle $z$ Warszawy i okolic (FELIKSIAK 1987b).

Znaczna część materiałów malakologicznych zgromadzonych w warszawskim Muzeum została pozyskana przez pracowników podczas wypraw w różne części świata. Należy wymienić podróże Polskiej Ekspedycji Zoologicznej do Brazylii (1921-1924), Tenenbauma i Wolskiego do Meksyku (1926), ponownie Wolskiego i Jaczewskiego do Meksyku (1929), Wacława Roszkowskiego (18861944) i Stanisława Feliksiaka (1906-1992) do Brazylii i na Martynikę (1931-1932), Janusza Nasta (1908-1991) i Roszkowskiego do Brazylii (1933-1934) oraz Feliksiaka i Jaczewskiego do Kanady (1938) (WA_SOWSKA i WINISZEWSKA-ŚLIPIŃSKA 1996).

W okresie powojennym kolekcje malakologiczna rozwijał Adolf Riedel (1930-2010), zwiazany $z$ muzeum w latach 1949-1999. Przekazał ponad 40000 okazów zebranych podczas badań terenowych prowadzonych w różnych częśsiach świata (m.in. we Włoszech, w Rosji, Rumuni, Austrii, Grecji, Francji, Bułgarii, Algierii, Maroku, Libanie, Syrii, Turcji, Korei Północnej i na Kubie). Dorobkiem Riedla jest zbiór ślimaków $z$ rodziny Zonitidae, liczacy około 350 gatunków palearktycznych, w tym około 150 gatunków reprezentowanych przez okazy typowe. Dzięki licznym preparatom anatomiczno-syste- 
matycznym zbiór jest uważany za unikatowy w skali europejskiej i światowej, zaś Zonitidae za najlepiej poznane pod względem anatomii, taksonomii i rozmieszczenia (WIKTOR i współaut. 2010, MIERZWA-SZYMKOWIAK 2012).

\section{KOLEKCJA ARACHNOLOGICZNA}

Kolekcja arachnologiczna MiIZ PAN jest jedna $z$ najstarszych na świecie $i$ jeszcze $w$ latach 60. XX w. była zaliczana do największych, główne dzięki licznym ekspedycjom organizowanym przez polskich arystokratów do bogatych w gatunki regionów tropikalnych i subtropikalnych (Afryka i Ameryka Południowa). Do powiększenia kolekcji oraz jej znaczenia przyczyniło się również nabycie okazów $z$ Indonezji i Australii, często w ramach wymiany między badaczami. Współcześnie pozyskane okazy pochodza głównie $z$ badań faunistycznych prowadzonych od drugiej połowy lat 50. przez Jerzego Prószyńskiego i Wojciecha Staręge (1939-2015), przeważnie w kraju oraz częściowo w Bułgarii czy Ghanie. Obecnie kolekcja pajęczaków liczy ponad 200000 okazów, z czego prawie $50 \%$ stanowi część historyczna $z$ lat 1864-1919, tworzona przez Władysława Taczanowskiego i Władysława Kulczyńskiego, krakowskiego przyrodnika, nauczyciela, profesora, i przede wszystkim światowej sławy arachnologa.

Pochodzacy $z$ Lubelszczyzny Taczanowski w świecie nauki znany jest jako ornitolog, niemniej jego znaczacy wkład w rozwój zarówno polskiej, jak i światowej arachnologii jest równie imponujacy. Konserwator zbioru ornitologicznego przy sekcji leśnej Gubernialnego Zarzadu Radomskiego, zdobywał doświadczenie także w muzeach europejskich, m.in. w Wiedniu, Berlinie, Paryżu $i$ Londynie. Od 1855 r. był pracownikiem Gabinetu Zoologicznego przy Szkole Głównej w Warszawie, a następnie jego kustoszem (od 1862). Prowadzony przez Taczanowskiego Gabinet Zoologiczny uważany był za czołowy polski ośrodek w zakresie badań światowej fauny. Sam Taczanowski „stał się rzecznikiem polskich pozaeuropejskich badań przyrodniczych, inicjatorem licznych wypraw naukowych oraz opiekunem i doradca podróżników polskich" (SŁABCZYŃSKI i SŁABCZYŃSKI 1992). Taczanowski organizował wyprawy naukowe w różne części świata: do Ameryki Południowej, na Syberię, do Afryki, a materiały pozyskiwane były głównie przez Jelskiego i Sztolcmana. Także Dybowski (Ryc. 13) i Nikołaj Przewalski (18391888) dostarczali do Gabinetu interesujace materiały ze swoich wypraw na Syberię czy do środkowej i wschodniej Azji. Z kolei Aleksander Karpiński (1836-1887) przekazał swoją kolekcję pajęczaków $\mathrm{z}$ terenów obec-

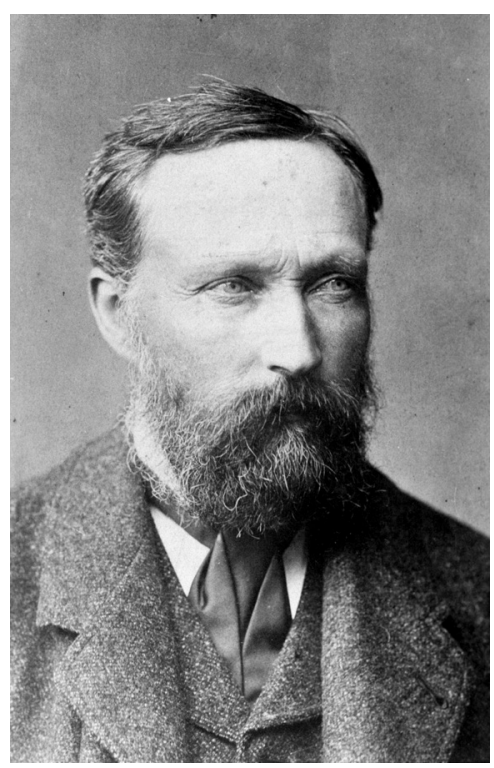

Ryc. 13. Benedykt Dybowski (1833-1930). Archiwum MiIZ PAN.

nej Ukrainy. Taczanowski, poza organizacja wypraw i pozyskiwaniem okazów zoologicznych od podróżników, w latach 1866-1867 odbył podróż badawcza do Algierii i w głąb Sahary wraz $z$ Aleksandrem i Konstantym Branickimi oraz Antonim Waga (1799-1890), mecenasami podróżnictwa naukowego. Sam opracowywał materiał, a okazy przywiezione z egzotycznych regionów stały się podstawa opisów ponad 100 nowych gatunków przez Taczanowskiego lub innych ówczesnych przyrodników, jak: Eugen von Keyserling (1832-1889), Eugène Simon (1848-1924), czy Tord Tamerlan Teodor Thorell (18301901). Z punktu widzenia naukowego najcenniejsze okazy w zbiorze Taczanowskiego pochodza z Ameryki Południowej. Stanowia one pierwsze opracowanie pajakków z Gujany Francuskiej i Peru, a typy sa podstawa znajomości tej fauny. Opracowanie krajowej arachnofauny przez Taczanowskiego obejmuje pajaki Warszawy oraz okolic $i$ jest ważnym, także obecnie, odniesieniem dla badań faunistycznych.

Po II wojnie światowej kolekcja pajęczaków ówczesnego Państwowego Muzeum Zoologicznego składała się głównie ze zbiorów Taczanowskiego i w mniejszym wymiarze ze zbiorów kolejnych kierowników m.in. Polińskiego, Roszkowskiego, Janusza Domaniewskiego (1891-1954). W 1951 r. znaczna część kolekcji stanowiły zbiory Kulczyńskiego, który mawiał, że jego kolekcja jest trzecia na świecie, po zbiorach British Museum i Simona w Paryżu (KAWECKI 1967). Kolekcja Kulczyńskiego stanowi ok. 40\% kolekcji pajęczaków MiIZ PAN i obejmuje okazy ze wszystkich kontynentów ( $z$ wyjątkiem An- 
tarktydy), za sprawa licznych kontaktów naukowych, jakie zrodziły się dzięki jego doskonałej znajomości gatunków. Specjaliści m.in. z Paryża, Londynu i Niemiec pisali do niego $z$ prośba o potwierdzenie oznaczenia lub w ogóle o identyfikację danego okazu. W kolekcji Kulczyńskiego znajduje się ponad 1100 okazów typowych reprezentujacych 200 nazw gatunkowych.

Sam Kulczyński podróżował niewiele. Jego zbiory obejmuja głównie pajaki $z$ tatrzańskich wędrówek, okolic Krakowa, a także z pojedynczych wyjazdów w Tyrol (1886), na Węry oraz na wybrzeża Morza Północnego i Adriatyku. Pajęczaki z obszaru Galicji, poczawszy od 1866 roku, pochodza głównie ze zbiorów Leopolda Wajgla (1842-1906), Jana Jachno (1840-1895) i Maksymiliana Nowickiego (1826-1890). Te ostatnie (1873) oznaczył Ludwig Koch (1825-1908) z Norymbergii (KULCZYŃSKI 1901). Bogata część całej kolekcji stanowia zbiory $z$ Węgier $i$ Chorwacji, opracowane i opublikowane w latach 1891-1897, jako epokowe dzieło pod nazwa "Araneae Hungariae", we współpracy z Kornelem Chyzerem (1836-1909). Kolejne ważne dzieło Kulczyńskiego to seria we „Fragmenta Arachnologica" (tomy 1-18, 1905-1915) dotycząca pajęczaków, m.in. z Cypru, Palestyny, Syrii i innych obszarów basenu Morza Sródziemnego. Znaczną część kolekcji stanowia okazy pozyskane $\mathrm{z}$ Mozambiku (1892-1893, 1906-1909), głównie dzięki współpracy z misjonarzami, którzy za upominki, np. noże, wysyłali do Krakowa afrykańskie pająi. W kolekcji arachnologicznej MiIZ PAN znajduja się ponadto materiały $z$ Syberii, Spitsbergenu, Azji Mniejszej, Bałkanów, Kaukazu, Tyrolu, Madery, Indonezji, które doczekały się kolejnych opracowań przez samego Kulczyńskiego (ponad 40 prac). Natomiast część pajaków, nie tylko z Polski, ale także wymienionych obszarów, jest jeszcze nieoznaczona. Jednak dzięki digitalizacji zbiorów historycznych w ramach projektu IMBIO, dane te zostana udostępnione do badań.

\section{KOLEKCJA CHRZĄSZCZY SZYMONA TENENBAUMA}

W 1947 r. żona Szymona Tenenbauma, Eleonora Tenenbaum-Krajewska (18921967), podarowała Państwowemu Muzeum Zoologicznemu zbiór chrząszczy swojego męża, który zmarł $z$ wycieńczenia 29 listopada 1941 r., zamknięty $z$ cała rodzina w getcie warszawskim. Oprócz nielicznych dokumentów i blisko 30 publikacji, a także pokaźnego księgozbioru, pozostały po nim zbiory owadów oraz gadów i płazów, znajdujace się obecnie w wielu muzeach i kolekcjach prywatnych. Najsłynniejsza $z$ nich - kolekcja chrząszczy, zawierająca blisko
250000 okazów, zebranych we wszystkich zakatkach świata, znajduje się obecnie w MiIZ PAN w Warszawie. Jej dramatyczna historia zwiazana $z$ Warszawskim Ogrodem Zoologicznym oraz takimi postaciami jak Antonina i Jan Żabińscy, została opisana i udokumentowana w licznych publikacjach i książkach (ACKERMAN 2007), nakręcono film pt "Azyl" (ang. The Zookeeper's Wife). Tuż przed wybuchem Powstania Warszawskiego, Żabiński przeniósł kolekcje chrząszczy zgromadzona w kilkuset gablotach do gmachu PMZ na ulicę Wilcza 64. Tutaj przetrwała ona wojnę $\mathrm{w}$ preparatorni, która mieściła się w piwnicy Muzeum. Takiego szczęścia nie miały pozostałe, najstarsze polskie zbiory entomologiczne, ponad 3000000 okazów, które uległy zniszczeniu po podpaleniu budynku już po upadku powstania (DASZKIEWICZ i IWAN 2016). Zbiór chrząszczy jednego z najwybitniejszych światowych entomologów jest dowodem jego pasji naukowej (patrz IWAN i DASZKIEWICZ w tym zeszycie KOSMO$\mathrm{SU})$, którą mógł realizować dzięki dwóm kobietom jego życia: żonie Eleonorze i córce Irenie. Kolekcja ta jest również świadectwem historii Polski, a także głębokiego patriotyzmu jej Autora, który na znak swojego przywiazania do ojczyzny nazwał jeden $z$ gatunków chrząszczy Isomira polonica Tenenbaum, 1922.

W latach 2014-2015 kolekcja została uporządkowana i częściowo zdigitalizowana. Towarzyszyły temu badania dokumentacji archiwalnej i działalność edukacyjna, która przy współpracy z Fundacją Panda oraz Stowarzyszeniem Monopol Warszawski, zakończyła się włączeniem materiałów dotyczących kolekcji do stałej ekspozycji w Warszawskim Ogrodzie Zoologicznym opisujacej historię ratowania Żydów w czasie okupacji niemieckiej. To właśnie w willi Żabińskich przechowywany był w czasie wojny zbiór chrząszczy Tenenbauma, a Żabiński wykorzystał go jako jeden ze sposobów wyprowadzania $z$ getta wielu ludzi.

Po uporzadkowaniu, kolekcja składa się $z$ dwóch części. Jedną stanowi fragment zbioru przechowywany w autentycznych gablotach i pudłach Tenenbauma, w których zachowane zostało oryginalne rozmieszczenie okazów i etykiet $z$ nazwami taksonów (Ryc. 14). Ta wydzielona i nie właczona do zbioru ogólnego część kolekcji Tenenbauma liczy 171 gablot drewnianych, oszklonych, o wymiarach ca 41 x 31 x $7 \mathrm{~cm}$ i 5 pudeł tekturowych o wymiarach ca 40 x 30 x $7 \mathrm{~cm}$. Druga część kolekcji tworza okazy dołaczone do ogólnego zbioru skomasowanego i uporzadkowanego zgodnie $z$ układem systematycznym poszczególnych rodzin chrząszczy (Ryc. 15). Okazy $z$ kolekcji Te- 


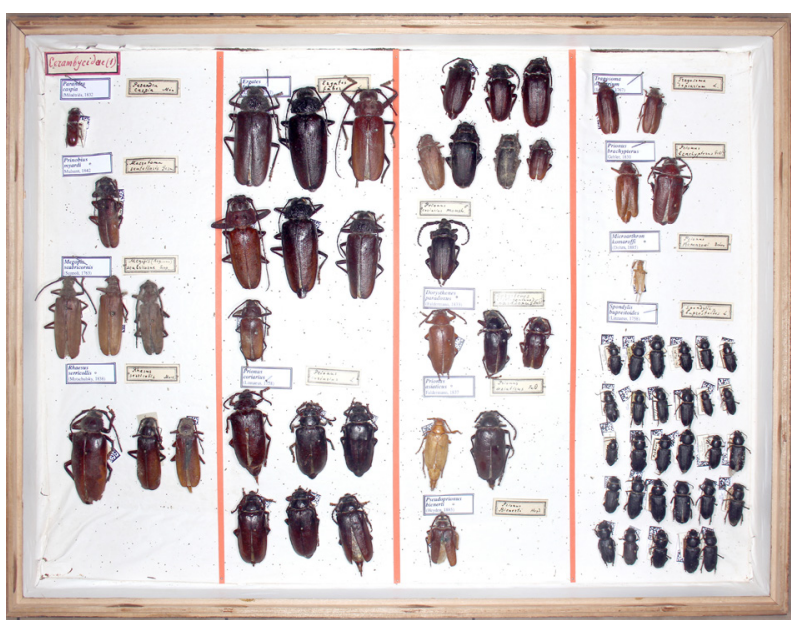

Ryc. 14. Chrząszcze $z$ rodziny kózkowatych (Cerambycidae) w kolekcji Szymona Tenenbauma, pierwotny układ w oryginalnej gablocie, fot. $M$. Kamiński.

nenbauma można zidentyfikować po załaczonych etykietach muzealnych o treści: „ex coll. Sz. Tenenbaum Mus. Zool. Polonicum Warszawa 38/47". Przed przystapieniem do prac inwentaryzacyjnych sporzadzono dokumentację fotograficzna autentycznych gablot entomologicznych Tenenbauma, w których zachował się jeszcze oryginalny porzadek $\mathrm{w}$ rozmieszczeniu poszczególnych gatunków sporzązony przez autora kolekcji (patrz: Naukowe Centrum Dokumentacji Przyrodniczej, https://ncdp.ksib.pl/tenenbaum/collection/specimens). W sumie wykonano 1710 zdjęć gablot, po 10 dla każdej - rzut ogólny i 9 powiększonych obszarów, a także blisko 2000 fotografii pojedynczych etykiet znajdujacych się na szpilkach przy poszczególnych okazach. Ta część zdigitalizowanych materiałów trafiła do projektu „Mapa Bioróżnorodności", który został zrealizowanego w ramach Krajowej Sieci Informacji o Bioróżnorodności (KSIB).

W czasie tworzenia swojej kolekcji Tenenbaum współpracował $z$ wieloma entomologami na całym świecie, nie tylko $\mathrm{w}$ zakresie zdobywania okazów $z$ odległych regionów, ale także w celu uzyskania pomocy przy ich oznaczaniu. Często udostępniał swoje chrzaszcze do opracowania wybitnym specjalistom od poszczególnych grup systematycznych Coleoptera, co sprawiło, że kolekcja zyskała na wartości naukowej i historycznej. $Z$ długiej listy znanych entomologów, $z$ którymi Tenenbaum współpracował, można wymienić takie osoby, jak: V. Balthasar (Scarabaeidae), M. Bernhauer (Staphylinidae), N. Bruce (Cryptophagidae), F. Español (Scarabaeidae), L. Falcoz (Cryptophagidae), J.J.E. Gillet (Scarabaeidae), J. Györffy (Apionidae), A. Jedlička (Carabidae), V. Machulka (Sta-

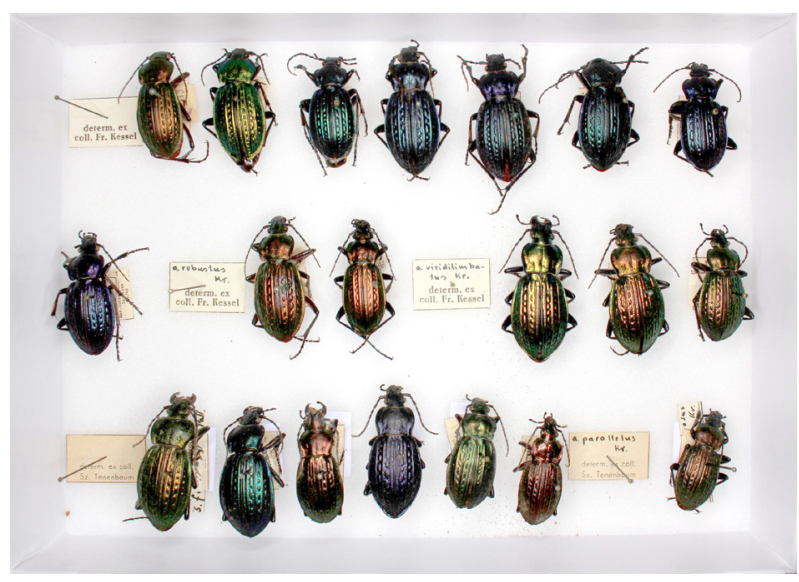

Ryc. 15. Chrzaszcze należące do gatunku Carabus ullrichii Germar, 1824 w skomasowanej kolekcji systematycznej, fot. M. Kamiński.

phylinidae), R. Mamitza (Heteroceridae), R. Mikšić (Scarabaeidae), J. Obenberger (Buprestidae), K.A. Penecke (Curculionidae), N. Plavilstshikov (Cerambycidae), F. Rambousek (Staphylinidae), E. Reitter (liczne grupy), J. Roubal (liczne grupy), E. Schauberger (Carabidae), H. Schleicher (Histeridae), O. Sjöberg (Cryptophagidae, Staphylinidae), H. Wagner (Apionidae, Curculionidae), E. Voß (Curculionidae). Wśród okazów znajdujących się w kolekcji sa egzemplarze bardzo cenne, przede wszystkim ze względów historycznych. Należą do nich: chrzaszcze pozyskane przez Dybowskiego i Godlewskiego na Syberii w latach 1871-1872, złowione przez Jelskiego w Peru w 1872 r. oraz zebrane przez Sztolcmana podczas wypraw do Peru i Ekwadoru w 1876 r. Sa też okazy złowione przez Taczanowskiego podczas wyprawy do Algierii zorganizowanej na przełomie 1866/1867 przez Konstantego i Aleksandra Branickich (DASZKIEWICZ i współaut. 2017). Wyniki dotychczasowych badań wskazuja, że w zbiorze chrzaszczy Tenenbauma zachowały się nieliczne egzemplarze naszego dziedzictwa narodowego, które przetrwały pożar w 1935 r. w PMZ na Krakowskim Przedmieściu, czy też celowe podpalenie przez Niemców budynku przy ulicy Wilczej 64. Najstarsze okazy zdeponowane w kolekcji Tenenbauma pochodza $z$ Wilna $z 1840$ r. (dotychczas natrafiono na kilkanaście chrząszczy należących do różnych rodzin, autor zbioru jest nieznany), a okazy najpóźniej zebrane, jakie udało się odnaleźć w kolekcji, to drobne chrząszcze $z$ rodziny Ptiliidae złowione $w$ dniu 29 września 1940 r. w mieszkaniu w Warszawie. Data ta zbiega się $z$ data 16 listopada 1940 r., kiedy to mury warszawskiego getta zostały zamknięte, a Tenenbaum wraz $z$ ro- 


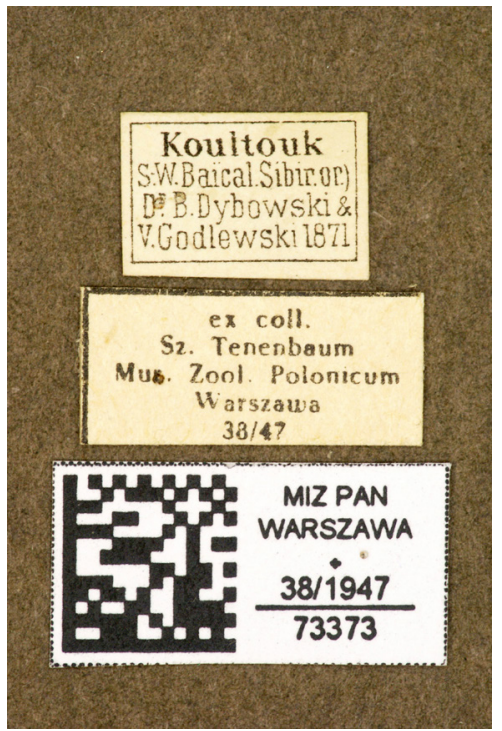

Ryc. 16. Etykiety owadów przekazanych przez Benedykta Dybowskiego i Wiktora Godlewskiego (Kułtuk, okolice Bajkału), kolekcja Szymona Tenenbauma, fot. T. Huflejt.

dzina musiał opuścić mieszkanie przy ulicy Poznańskiej, a sam zbiór umieścić w ZOO.

\section{KATALOG KOLEKCJI CHRZĄSZCZY (1942-43)}

Skale wojennych strat doskonale obrazuje ocalały $z$ wojny katalog części zbioru chrzasszczy, który został sporządzony w latach 1942-43 przez trzech entomologów wolontariuszy pracujacych w PMZ. Roman Kuntze (1902-1944), Józef Makólski (18811954) i Antoni Goljan (1915-1979) skomasowali i spisali informacje o blisko 40000 okazów należących głównie do rodzin: Curculionidae, Buprestidae, Elateridae, Chrysomelidae, Carabidae, Staphylinidae i Scarabaeidae. W ramach projektu IMBIO katalogi te zostały zdigitalizowane i będa udostępniane do dalszych analiz np. zoogeograficznych lub historycznych. Blisko 11000 rekordów zawiera informacje o chrzaszczach pochodzacych $z$ kolekcji prywatnych i instytucjonalnych (np. Muzeum Dzieduszyckich). Zostały one zebrane i oznaczone przez kilkudziesięciu przyrodników $z$ całego świata (Adamczewski, Bachinger, Bartoszyński, Bredow, Chmielewski, Ciszkiewicz, Ettlinger, Gajl, Gottwald, Heyne, Hildt, Karpowicz, Krauss, Kremky, Krüger, Nast, Poliński, Raabe, Roszkowski, Smreczyński, Stöcklein, Toll, Wagner, Wanka, Wańkowicz, Węrzecki, Xsieżopolski, Żywno). Materiały pochodziły głównie $z$ różnych regionów przedwojennej Polski i Europy (m. in. Austria, Niemcy, Włochy, Rosja, Szwajcaria, Bułgaria, Węgry, Jugosławia, Ukraina, Grecja, Gruzja, Algier, Korsyka, Sardynia). Były też okazy z Chin zbierane przez Wierzejskiego oraz Sybe-

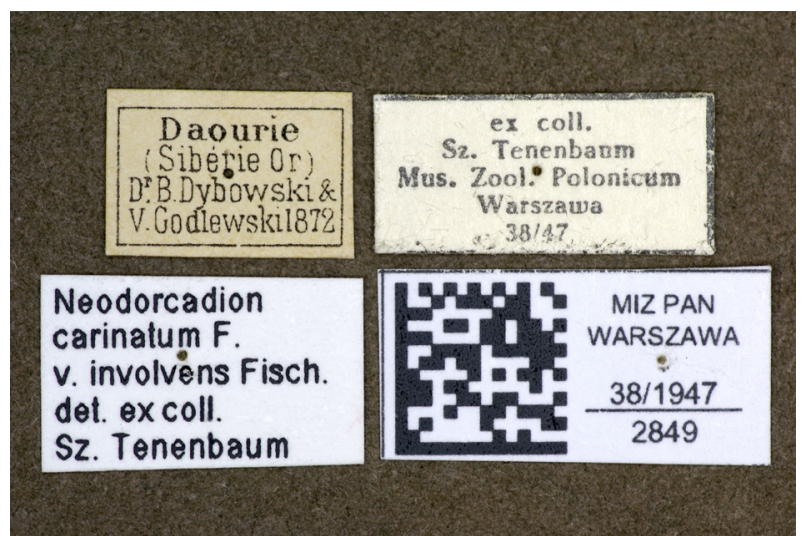

Ryc. 17. Etykiety owadów przekazanych przez Benedykta Dybowskiego i Wiktora Godlewskiego (Dauria, Syberia), kolekcja Szymona Tenenbauma, fot. T. Huflejt

rii (Sidemi, Kułtuk, Bajkał, Dauria) - przez Dybowskiego, Godlewskiego i Jankowskiego (Ryc. 16, 17). Najstarsze egzemplarze pochodziły $z$ kolekcji Ludwika Fryderyka Hildta (1847-1919) i były zaopatrzone w etykiety $z$ numerem nabytku 268/37, oznaczającym przekazanie materiałów na stan PMZ w 1937 r., np. „Lamia textor, 1860-75, Warszawa coll. Hildt 268/37, R. Kuntze 1943, 5 okazów" [obecnie: Lamia textor (Linnaeus, 1758), Cerambycidae]. Jeden osobnik został zebrany w 1860 roku przez Sznabla: „Corymbites purpureus, 1860, Ojców, Schnabl, R. Kuntze 1943, 1 okaz" [obecnie: Anostirus purpureus (Poda von Neuhaus, 1761), Elateridae].

\section{PERSPEKTYWY BADAWCZE}

Realizacja projektu IMBIO i uzyskane informacje o zasobach polskich instytucji naukowych umożliwia prowadzenie analiz zoogeograficznych, ekologicznych i taksonomicznych, jak również badań w zakresie historii dziedzictwa narodowego i historii zoologii. Wyniki digitalizacji pozwalaja także na powiazanie informacji zawartych w zbiorach przyrodniczych oraz danych $z$ dokumentów archiwalnych i publikacji, w tym o charakterze historycznym. Problem rabunków i strat wojennych polskich zbiorów przyrodniczych do tej pory badany był głównie w kontekście spraw osobowych (BRZEK 1997) i bez zastosowania odpowiednich metod badawczych wykorzystujacych bazy danych. Projekty realizowane przez KSIB, w tym IMBIO, moga przyczynić się do podjęcia efektywnej współpracy naukowców reprezentujących różne dyscypliny naukowe. Takim przykładem może być np. projekt realizowany w ramach Narodowego Programu Rozwoju Humanistyki MNiSW pt. „Rekonstrukcja 
i opracowanie zbiorów naukowych Gabinetu Zoologicznego Uniwersytetu Warszawskiego. Od XVIII-wiecznego Musaeum Polonicum do Narodowego Muzeum Przyrodniczego", w którym udział biora naukowcy Uniwersytetu Warszawskiego oraz Muzeum i Instytutu Zoologii PAN.

\section{PODZIEKKOWANIA}

Autorzy składaja podziękowania prof. Stanisławowi Knutelskiemu za cenne uwagi przekazane w czasie redagowania tekstu.

$$
\text { Streszczenie }
$$

Historia kolekcji zwierzat współczesnych Muzeum i Instytutu Zoologii PAN sięga II połowy XVIII w. Najstarsze okazy pochodza z kolekcji Sylwiusza Münkwitza, która stała się fundamentem zbiorów Gabinetu Zoologicznego Uniwersytetu Warszawskiego (1818-1919). W ciagu stu lat istnienia instytucja ta zgromadziła największa kolekcje zoologiczna o charakterze naukowym w Polsce i jedna $z$ największych w Europie. Grono osób, które pielęgnowało tradycje przyrodoznawcze obejmowało zarówno (1) eksploratorów terenu, odkrywców nowych dla nauki gatunków, jak i (2) przyrodników wyznaczających nowe kierunki oraz regiony badań, (3) mecenasów polskiej nauki, którzy wspierali tworzenie i utrzymywanie cennych kolekcji przyrodniczych, a także (4) zesłańców oraz emigrantów, którzy służyli polskiej nauce w odległych stronach świata. Pomimo represji zaborców, które dotknęły Gabinet Zoologiczny UW, od 1887 r. działalność eksploracyjną i muzealna kontynuowali przyrodnicy skupieni wokół Muzeum Branickich. Kolekcje obu instytucji stały się w 1919 r. kamieniem węgielnym zbiorów zoologicznych Narodowego Muzeum Przyrodniczego, którego sukcesorem, poprzez Polskie Państwowe Muzeum Przyrodnicze i Państwowe Muzeum Zoologiczne, jest obecnie Muzeum i Instytut Zoologii PAN. Tworzone z zaangażowaniem i znawstwem kolekcje obejmuja okazy reprezentujace tysiace gatunków (w tym typy opisowe) występujacych na wszystkich kontynentach świata. Od wielu lat służa one nauce, edukacji i popularyzacji wiedzy przyrodniczej. Burzliwe dzieje Polski, a zwłaszcza druga wojna światowa nie sprzyjały rozwojowi kolekcji. Zbiory były niszczone, konfiskowane i wywożone, wiele $z$ nich uległo rozproszeniu. Po wojnie na nowo podjęto gromadzenie, katalogowanie oraz upowszechnianie wiedzy o zasobach muzealnych. Informacje dotyczace tysięcy okazów przechowywanych obecnie w MiIZ PAN w Warszawie łaczy jeden spójny system umożliwiajacy prezentowanie zbiorów w formie cyfrowej, która dociera do szerokiego grona odbiorców.

\section{LITERATURA}

ACKERMAN D., 2007. The Zookeeper's Wife: A War Story. W.W. Norton \& Company, New York, 350 .

BRZEK G.,1959. Złoty wiek ornitologii polskiej. Memorabilia Zoologica 3, 1-175.

BRZEK G., 1994. Benedykt Dybowski. Życie i dzie Ło. Polskie Towarzystwo Ludoznawcze, Warszawa-Wrocław.

BRZEK G., 1997. Straty wśród zoologów polskich $w$ nastepstwie II wojny światowej. Analecta. Studia i Materiały $z$ Dziejów Nauki 6, 173197.
DASZKIEWICZ P., IWAN D. 2016. Straty wojenne Państwowego Muzeum Zoologicznego - raport Stanisława Feliksiaka (1906-1992). Pamięć i Sprawiedliwość 27, 431-439.

DASZKIEWICZ P., IWAN D., 2020. Co wiemy o $\mathrm{Mu}$ zeum Branickich? Listy Jana Sztolcmana do Benedykta Dybowskiego ze zbiorów poznańskiego oddziału Archiwum PAN - interesujacy przyczynek dla historii zbiorów przyrodniczych $w$ Polsce. Kwartalnik Historii Nauki i Techniki 65, 77-87.

DASZKIEWICZ P., IWAN D., KOWALSKI H., MIERZWA-SZYMKOWIAK D., ZABOROWSKI R. 2016. 150-lecie Gabinetu Zoologicznego $w$ Warszawie (1818-1898). Memorabilia Zoologica NS 1, $1-202$.

DASZKIEWICZ P., IWAN D., KOWALSKI H., MIERZWA-SZYMKOWIAK D., ZABOROWSKI R. 2017. Z dziejów Gabinetu Zoologicznego. Materiały $z$ wy prawy do Algierii (1866-1867). Memorabilia Zoologica NS 2, 1-256.

FELIKSIAK S., 1987a. Eichler Witold. [W]: Słownik biologów polskich. FELIKSIAK S. (red.). PWN, Warszawa, 154-156.

FELIKSIAK S., 1987b. Jankowski Antoni. [W]: Słownik biologów polskich. FELIKSIAK S. (red.). PWN, Warszawa, 225-226.

FELIKSIAK S., 1987c. Poliński Władysław Karol Aleksander. [W]: Słownik biologów polskich. FELIKSIAK S. (red.). PWN, Warszawa, 428-429.

FELIKSIAK S., 1987d. Wagner Antoni Józef. [W]: Słownik biologów polskich. FELIKSIAK S. (red.). PWN, Warszawa, 559-560.

IWAN D. 2007. Rola muzeów przyrodniczych w badaniach bioróżnorodności. Wszechświat 108, 202-207.

IWAN D., DASZKIEWICZ P., 2019. Pojedynek uczonych - konflikt u zarania Narodowego $\mathrm{Mu}$ zeum Przyrodniczego $w$ Warszawie $w$ świetle zachowanej korespondencji Jana Sztolcmana (1854-1928) i Benedykta Dybowskiego (18331930). Echa Przeszłości XX, 419-429.

JASTRZEBBSKA M., 2005. Rokoko, dama i gilotyna. Historia księżnej Rozalii $z$ Chodkiewiczów Lubomirskiej. Wyd. Arcana, Kraków.

KAWECKI Z., 1967. Władysław Kulczyński (18541919). Memorabilia Zoologica 18, 1-112.

KAZUBSKI S.L., 1996. The history of the Museum and Institute of Zoology, PAS. Bulletin of the Museum and Institute of Zoology PAS 1, 7-19.

KOWALSKA K., 1973. Lubomirski Władysław Emanuel. [W]: Polski słownik biograficzny (Lubomirski Aleksander-Lutostański Seweryn). RoSTWOROWSKI E. (red.). Wrocław, Warszawa, Kraków i Gdańsk 18, 63-65.

KOWALSKA K., 1987a. Andraszek Edmund. [W]: Słownik biologów polskich. FELIKSIAK S. (red.). PWN, Warszawa, 48.

KoWALSKA K., 1987b. Branicki Aleksander. [W]: Słownik biologów polskich. FELIKSIAK S. (red.). PWN, Warszawa, 86.

KoWALSKA K., 1987c. Branicki Konstanty. [W]: Słownik biologów polskich. FELIKSIAK S. (red.). PWN, Warszawa, 86-87.

KowALSKA, K., 1987d. Jelski Konstanty Roman. [W]: Słownik biologów polskich. FELIKSIAK S. (red.). PWN, Warszawa, 234-235.

KOWALSKA K., 1987e. Lubomirska Zofia. [W]: Słownik biologów polskich. FELIKSIAK S. (red.). PWN, Warszawa, 333.

KOWALSKA K., 1987f. Lubomirski Władysław Ema nuel. [W]: Słownik biologów polskich. FELIKSIAK S. (red.). PWN, Warszawa, 333.

KULCZYŃSKI W., 1901. O stanie badań fauny krajowej. Kosmos 26, 205-223. 
LUBOMIRSKI-LANCKOROŃSKI J., 2018. Zofia z Krasinskich primo voto Tarlowa secundo voto $\mathrm{Lu}$ bomirska. [W]: Lubomirscy Ksiażęta Polscy. Historia rodu Ksiażat Lubomirskich od złotego wieku do Konstytucji 3 maja (XVII-XVIII w.). SzMAJDA D. (red.). Wyd. Sorus, Kraków-Poznań, 2, 187-188.

MIERZWA-SZYMKOWIAK D., 2012. Profesor Adolf Riedel (1930-2010). Wspomnienie. Nowy Pam. Fizjograficzny $7,2-5$.

MiERZWA-SZYMKOWIAK D., BREURE A. S. H., 2017. Inside and outside the Neotropics: three Polish naturalists during the late nineteenth and ear ly twentieth centuries. Archiv. Nat. Hist. 44, $151-158$

PAWŁOWSKI J., 2006. Szkic rozwoju zoologii na ziemiach polskich. Kosmos 55, 5-44

PIECHNIK Ł., KUREK P., 2016. Ssaki neotropików odkryte przez polskich naturalistów. Instytut Botaniki im. W. Szafera PAN, Kraków.

PoKRYSZKO B. M., RIEDEL A., 1999. Polish malacology - past, present and future. Folia Malacol. 7, 275-291.

POLIŃSKI W., 1929. Antoni J. Wagner 1860-1928. Ann. Musei Zoologici Polonici 8, 15-22.

RAVEn P. H., WAGNER D. L., 2021. Agricultural intensification and climate change are rapidly decreasing insect biodiversity. Proc. Natl. Acad. Sci. USA 118, 1-6.

RolSKA-BORUCH I., 1999. Pałac $w$ Opolu Lubelskim. Jego dzieje $i$ zbiory. Roczniki Humanistyczne XLVII, 141-153.

Richling I., 2005. Biographical remarks on $\mathrm{dr}$. Antoni Józef Wagner and the collection of $\mathrm{He}$ licinidae (Gastopoda: Neritopsina) at the Muzeum and Institute of Zoology in Warsaw. Folia Malacologica 13, 197-206.

Riedel A., POKRYSzKo B. M., 1999. Malakologia polska. Historia, stan obecny, perspektywy. Tomik pamiatkowy wydany $z$ okazji 15 Krajowego Seminarium Malakologicznego. Stowarzyszenie Malakologów Polskich, Poznań.

SŁABCZYŃSKI W., SŁABCZYŃSKI T., 1992. Słownik podróżników polskich. Wiedza Powszechna, Warszawa.

SUCHODOLSKI B., SKUBAŁA-TOKARSKA Z., RYBKA E., PAWlikowska-BrożeK Z., PIECH T., HuBICKI W., KOWALSKA K., KOSIEK Z., BRZOZOWSKI S., SZPILCZYŃSKI S., DZIERŻYKRAY-ROGALSKI T. 1983. Zarys dziejów nauk przyrodniczych $w$ Polsce. Wiedza Powszechna, Warszawa.
SzTolcman J., 1888. Muzeum zoologiczne hr Branickich. Wszechświat 7 , III.

SzTOLCMAN J., 1890. Władysław Taczanowski. Wszechświat 9, 50-53.

TACZANOWsKI W., 1884. Hrabia Konstanty Branicki. Wszechświat 3, 450-452.

TARKOWSKI R., 2011. Konstanty Jelski (18371896). Przyrodnik $i$ badacz Ameryki Potudniowej. Wydawnictwo Naukowe Uniwersytetu Pedagogicznego, Kraków.

WAGNER A., 1926a. Sprawozdanie Dyrektora za rok 1919, 1920 i 1921. (Rapport du Directeur). Ann. Zoologici Musei Polonici Historiae Naturalis $6,251-260$.

WAGNER A., 1926b. Sprawozdanie Dyrektora za rok 1922. Ann. Zoologici Musei Polonici Historiae Naturalis 6, 260-263.

WAGNER A., 1926c. Sprawozdanie Dyrektora za rok 1923. Ann. Zoologici Musei Polonici Historiae Naturalis 6, 264-267.

WAGNER A., 1926d. Sprawozdanie Dyrektora za rok 1924. Ann. Zoologici Musei Polonici Historiae Naturalis 6, 267-273.

WAGNER A., 1926e. Sprawozdanie Dyrektora za rok 1925. Ann. Zoologici Musei Polonici Historiae Naturalis 6, 273-278.

WAGNER A., 1926f. Sprawozdanie Dyrektora za rok 1926. Ann. Zoologici Musei Polonici Historiae Naturalis 6, 278-284.

WAGNER A., 1928. Sprawozdanie Dyrektora za rok 1927. (Rapport du Directeur). Ann. Zoologici Musei Polonici Historiae Naturalis, 7, 10-21.

WAGNER A., 1929. Sprawozdanie Dyrektora za rok 1928. (Rapport du Directeur). Ann. Zoologici Musei Polonici Historiae Naturalis 8, 1-14.

WĄSOWSKA M., WINISZEWSKA-ŚLIPIŃSKA G., 1996. The history of the collection of Neotropical fauna in the Museum and Institute of Zoology PAS until 1939. Bulletin of the Museum and Institute of Zoology PAS 1, 29-34.

WikTOR A., STWORZEWICZ E., MIERZWA D., 2010. Professor dr hab. Adolf Riedel February 24th 1930-August 21st 2010 .Obituary. Folia Malacologica $18,51-57$.

WRZEŚNIOWSKI A., 1882. Ksiaże Władysław Lubomirski. Wszechświat $1,5-8$.

WRZEŚNIOWSKI A., 1883. Władysław Taczanowski. Wszechświat 2, 358-362. 
KOSMOS Vol. 70, 2, 241-254, 2021

\author{
DARIUSZ IWAN, DOMINIKA MIERZWA-SZYMKOWIAK, WIOLETTA WAWER
}

Museum and Institute of Zoology PAS, Wilcza 64, 00-679 Warszawa,E-mail: darek@miiz.waw.pl, dmierzwa@miiz.waw.pl, awer@miiz.waw.pl

THE NATURAL HISTORY COLLECTIONS OF THE MUZEUM AND INSTITUTE OF ZOOLOGY PAS - TESTIMONY TO THE POLISH CONTRIBUTION TO THE DEVELOPMENT OF GLOBAL RESEARCH ON BIODIVERSITY SINCE THE BEGINNING OF THE $19^{\text {TH }}$ CENTURY

\title{
Summary
}

The history of the collection of contemporary animals of the Museum and Institute of Zoology PAS dates back to the second half of the 18th century. The oldest specimens come from the collection of Sylwiusz Münkwitz, which became the foundation of the assemblage of the Zoological Cabinet of the University of Warsaw (1818-1919). During the hundred years of its existence, this institution has gathered the largest zoological collection of scientific nature in Poland and one of the largest in Europe. The circle of people who cultivated natural science traditions included both (1) explorers of terrain, discoverers of species new to science and (2) naturalists who marked out new directions and regions of research, (3) patrons of Polish science who supported the creation and maintenance of valuable natural history collections, as well as (4) exiles and emigrants who served Polish science in distant parts of the world. Despite invaders' repressions against the Zoological Cabinet of the University of Warsaw, naturalists gathered around the Branicki Museum continued their exploratory and museum activities as of 1887 . The collections of both institutions became in 1919 the cornerstone of zoological collections of the National Museum of Natural History, whose successor - through the Polish State Museum of Natural History and the State Zoological Museum - is currently the Museum and Institute of Zoology PAS. Created with dedication and expertise, the collections include specimens representing thousands of species (including descriptive types) found on all continents of the world. For many years, they have been serving science, education and popularization of natural knowledge. The turbulent history of Poland, especially the Second World War, was not favorable for the development of the collection. Specimens were destroyed, confiscated and exported; many of them dispersed. After the war, collecting, cataloguing and disseminating knowledge about museum resources was resumed. Information on thousands of specimens is now linked in one coherent system. It enables the presentation of the collections in a digital form that reaches a wide audience.

Key words: biodiversity, Museum and Institute of Zoology Polish Academy of Sciences, museum specimens, national heritage, natural history collections, scientific collection 